\begin{tabular}{lc}
\hline & A N N A L E S \\
UNIVERS ITATIS & MARIAE C UR IE-S KŁODOW K A \\
LUBLIN - POLONIA & 2017 \\
VOL. XXIV, 1 & SECTIO K \\
\hline Institute of Political Science and International Affairs, John Paul II Catholic University of Lublin, Poland
\end{tabular}

\author{
MARCIN KOSIENKOWSKI
}

\title{
The Gagauz Republic: Internal Dynamics of De Facto Statehood ${ }^{*}$
}

\begin{abstract}
The post-Soviet area is a home for a several de facto states, which are entities that resemble "normal" states but lack international recognition. This paper examines a historical and under-researched case study of the Gagauz Republic (Gagauzia), a de facto state that existed within Moldova between 1990 and 1995. Drawing on a new suite of sources - interviews, memoirs and journalism - it analyses the territorial, military, political, and socio-economic dimensions of the Gagauz de facto statehood, tracing how the Gagauz authorities proceeded in consolidating Gagauzia's statehood through processes of state- and nation-building. This study concludes that the Gagauz leadership was moderately successful in its activities.
\end{abstract}

Key words: the Gagauz Republic, Gagauzia, de facto state, state-building, nation-building

\section{INTRODUCTION}

The post-Soviet area is a home for six de facto states: Abkhazia, Nagorno-Karabakh, South Ossetia, and Transnistria, as well as, in a historical perspective, Chechnya and the Gagauz Republic (Gagauzia). In short, de facto states resemble "normal" states except for one difference: they lack international recognition or enjoy it only

* The author would like to thank all persons interviewed during field research conducted in Moldova and Ukraine. Many of interviews were facilitated by Elena Cuijuclu from the Comrat State University, for which she deserves sincere thanks. The author also thanks: Mick Frogley for his support in editing the paper, Jakub Pieńkowski for drawing the map and the anonymous reviewers for their valuable comments. 
at a minimal level. This means that their territories formally belong to universally recognised states - in the above-mentioned cases, Azerbaijan, Georgia, Moldova, and Russia - although in reality the authorities of these parent states have no or limited control over their breakaway regions.

This article focuses on the Gagauz Republic established on the territory of Moldova by the Gagauz - Turkic-speaking Orthodox Christians. Having declared its independence from the then Soviet republic of Moldova on August 19, 1990, Gagauzia was the first Eurasian de facto state. De facto independence was achieved quickly, when Gagauzia endured Moldova's attempt to crush it by force at the end of October $1990 .{ }^{1}$ Further, Gagauzia was the only Eurasian de facto state to be voluntarily reintegrated by a parent state, becoming the Autonomous Territorial Unit of Gagauzia (Gagauz Yeri) within independent Moldova. Striking a deal with the Gagauz leadership, Moldova's parliament adopted a proper bill in December 1994, while the territory, governor (bashkan), and legislative body of autonomous Gagauzia were determined by popular vote in the following months in 1995 . The newly elected authorities inaugurated their work in June 1995 taking over power from the Gagauz Republic's leadership. ${ }^{2}$

While the body of literature on internal developments in present Eurasian de facto states is growing [for example, Kolstø, Blakkisrud 2008; Blakkisrud, Kolstø 2011, 2012; Ó Beacháin et al. 2016] and a historical case of Chechnya afforded consideration [Tishkov 2004; Graney 2004], the Gagauz Republic is largely overlooked. Although the Gagauz national movement and its conflict with the central Moldovan authorities have been reasonably well investigated [Batt 1997; King 1997; Chinn, Roper 1998; Thompson 1998; Webster 2007; Zabarah 2011, 2012], only a fragmentary and often contradictory account of the internal dynamics in the Gagauz Republic is given in the literature, and there are actually only two short works - written by Petr Shornikov and Stepan Bulgar [Shornikov 2006; Shornikov, Bulgar 2006] - that pay more detailed attention to this problem.

This paper aims to contribute to the scholarship on de facto states by examining how the Gagauz authorities proceeded in consolidating Gagauzia's statehood

1 Caspersen [2012: 12] and Florea [2014: 793] designate Gagauzia as a de facto state since 1991. They may point to the fact that Gagauzia announced independence only from Soviet Moldova, wanting to remain a part of the Soviet Union. Therefore, they may argue that Gagauzia de facto became an independent entity only when the Soviet Union was dissolved in December 1991. However, it can be argued that the Gagauz Republic was de facto independent from the Soviet Union as well. At the turn of the 1980s and 1990s, Moscow's control over its territory was waning, while the level of power and independence of Soviet republics, including those that were self-proclaimed, gradually increased. Accordingly, Kaufman [2001: 154] points out that by the summer of 1990, "Moscow was reduced more and more to the role of an outside intervener rather than a sovereign authority" in a conflict between Moldova and Gagauzia (and Transnistria).

2 Caspersen [2012: 12] and Florea [2014: 793] point respectively at 1994 and 1995 as the years when Gagauzia ceased to be a de facto state. The date when the Autonomous Territorial Unit of Gagauzia (Gagauz Yeri) was de facto established, i.e. (June) 1995, is a more appropriate end date for the de facto Gagauz state. 
through processes of state- and nation-building. Nina Caspersen [2012: 52] divides a state-building into a few, frequently overlapping phases: 1. Expelling representatives of a parent state and establishing physical control over (most of) the claimed territory; 2. Establishing a monopoly on the legitimate use of violence (including subordination of warlords) and credible military defence capabilities; 3. Providing basic public services to a population, not just internal and external security: this, in fact, relates to phase 2, but also such services as water and electricity, health and education. These processes are accompanied by nation-building, i.e. constructing a shared identity and a sense of unity in a de facto state's population [Kolstø, Blakkisrud 2008: 485]. In turn, advancements in state- and nation-building shape the legitimacy of a de facto state in the eyes of its population [Bakke et al. 2014: 592-594]. This article traces state- and nation-building processes by examining four domestic - i.e. the territorial, military, political, and socio-economic - dimensions of Gagauzia's de facto statehood.

The paper also aims to define the results of state consolidation efforts undertaken by Gagauzia's authorities. By putting Gagauzia on the list of de facto states, Nina Caspersen, Gareth Stansfield and Adrian Florea [Caspersen, Stansfield 2011: 3-4; Caspersen 2012: 11-12; Florea 2014: 791-793] acknowledge that this entity established control over (most of) the claimed territory. This view has supporters in the literature [Batt 1997: 40; Neukirch 2002: 107-108; Chinn, Roper 1998: 95; Thompson 1998: 135]. However, this and other state- and (presumably) nation-building efforts undertaken by Gagauzia's leaders are also frequently challenged in the literature. Steven D. Roper [2001: 117] claims that the assertion of Moldova's sovereignty over the Gagauz area was not seriously contested. Paul Kubicek [2010: 291] explains that Gagauzia's "protogovernment lacked the means to exercise control over the five districts under its purported administration". Similarly, Charles King [2000: 217] notes that the Gagauz region's sustenance depended on funding from Moldova's central budget. Accordingly, Sergey Markedonov [2015: 201] sees the Gagauz Republic as a failed de facto state, while Donnacha Ó Beacháin et al. [2016: 441] do not put Gagauzia on a list of Eurasian de facto states at all. Whereas this paper identifies deficiencies in state- and nation- building, it nevertheless concludes that the Gagauz authorities were moderately successful in consolidating Gagauzia's statehood.

The study is based predominantly on three kinds of sources. Firstly, there are thirty-five semi-structured interviews, mainly conducted with the leadership of the Gagauz Republic and activists of the Gagauz national movement. Secondly, the paper employs memoirs written by Mikhail Kendigelian [2009], a chairman of the Gagauz Republic's parliament, and by Stepan Topal [2013], the Republic's president. ${ }^{3}$ Thirdly, the study draws on newspapers published at the turn of the 1980s

\footnotetext{
3 Only the most important offices held by interviewees during the existence of the Gagauz Republic are mentioned in the paper. Proper names are provided in the text in their Russian, transliterated versions due to linguistic Russification of the Gagauz, whereas toponyms are provided in Moldovan (Romanian).
} 
and 1990s in four out of five of Moldova's districts, whose parts comprised the Gagauz de facto state: Leninskoe slovo/Komratskie Vesti - KV (Comrat), Znamia (Ceadîr-Lunga), Panorama (Vulcănești), and Svet Oktiabria - SO (Taraclia). This article starts by presenting the origins of the Gagauz Republic. Next, it analyses the territorial, military, political, and socio-economic dimensions of Gagauzia's de facto statehood, tracing processes of state- and nation-building. Finally, in a concluding section, it discusses how successful the Gagauz authorities were in consolidating Gagauzia's statehood.

\section{ORIGINS OF THE GAGAUZ REPUBLIC ${ }^{4}$}

The ethnic origin of the Gagauz is unclear. One of many hypotheses claims that they are Bulgarianised Turks, while another says they are Turkicised Bulgarians. What is widely accepted is that they resettled together with Bulgarians originating from Dobrudja (now in Bulgaria and Romania) to southern Bessarabia, known also as Budjak (now in Moldova and Ukraine) in the late eighteenth and early nineteenth century. This region was a part of the Russian Empire, then Romania and finally the Soviet Union. It was the Soviet republic of Moldova that became a home for the majority of the Gagauz people worldwide.

Despite the fact that under the rule of the Soviet Union the Gagauz advanced socially and economically, they were one of the most disadvantaged ethnic groups in Soviet Moldova. What enabled their national rebirth was perestroika, a programme of restructuring the Soviet Union launched in 1986 by Soviet leader Mikhail Gorbachev. The point was to preserve and foster their culture and boost economic development of their backward agricultural region. The Gagauz believed that their problems would be resolved if they were granted territorial autonomy within the Soviet republic of Moldova.

However, to the disadvantage of the Gagauz, the Moldovan national movement - led by the Popular Front of Moldova - grew more powerful and radical. It led to the adoption of language laws in autumn 1989 that granted official language status to Moldovan written in Latin script (which was, in fact, identical to Romanian). This move played against the dominantly Russian- or Gagauz-speaking Gagauz population, potentially jeopardising employment. Further, the Popular Front took power in Moldova in the aftermath of the 1990 parliamentary elections. New Moldovan national symbols were adopted, modelled on those of Romania, while the radical wing of the Popular Front was openly in favour of full reunion. The issue for the Gagauz was that the period when Moldova (Bessarabia) was a part of Romania was remembered in their collective memory as time of occupation and national oppression. The Popular Front also radicalised its position towards national minorities.

\footnotetext{
4 This section is based on works by Webster [2007], Shornikov [2006] and Zabarah [2011].
} 
These moves unsettled the Gagauz population and challenged the vested interests of local elites, consolidating the Gagauz national movement and strengthening the need for territorial autonomy (additionally guaranteeing internationalism and the official status not only for Gagauz, but also for the Russian language).

Despite growing tensions between Moldovans and the Gagauz, in August of 1989, they started a formal discussion on the question of Gagauz autonomy within Soviet Moldova. In order to press the Moldovans and push the autonomy issue forward, the Gagauz proclaimed the Gagauz Autonomous Soviet Socialist Republic on November 12, 1989. Although they then sought formal recognition from the Moldovan Supreme Soviet, their declaration was swiftly overturned and ruled illegal. Ultimately, on July 27, 1990, the Moldovan Supreme Soviet, controlled by the Popular Front of Moldova, refused to grant territorial autonomy to the Gagauz as a non-indigenous ethnic group and ruled that they had no rights to Moldova's land. The Gagauz, represented by people's deputies at all levels from the Gagauz area (from villages to the Soviet Union's Supreme Soviet), responded on August 19, 1990, with the establishment of the Gagauz Republic, an entity independent from Soviet Moldova but remaining a part of the Soviet Union. However, as John A. Webster [2007] convincingly argues, getting a territorial autonomy within Soviet, and then independent Moldova was still a principal aim of the Gagauz elites.

\section{TERRITORIAL DIMENSION}

A territorial issue was an open question from the beginning of the Gagauz national movement. While there had been no Gagauz territorial unit previously, or natural borders that could easily be incorporated, the Gagauz claim referred to Moldova's five southern districts, namely Basarabeasca, Ceadîr-Lunga, Comrat, Taraclia, and Vulcănești, home to almost all of Moldova's Gagauz (Table 1). During discussions on autonomy in 1989, the Gagauz came up with two basic proposals, albeit tentative [Sato 2009: 147-149]. The first concerned territories of all five districts. However, the problem was that the Gagauz comprised just $47.2 \%$ of that region's entire population, constituting an absolute majority in only two districts: Ceadîr-Lunga and Comrat. To make the proposal more credible, the Gagauz even tried to convince the Bulgarians to support and join the autonomy; indeed, the prospect of creating a dualistic Gagauz-Bulgarian autonomous entity was once floated. However, the Bulgarians rejected these offers [SO, Sept. 23, 1989; SO, Nov. 14, 1989]. The second proposal involved about half of the territory across the five districts, where there was concentration of the Gagauz. One of its variants included localities where Gagauz had an absolute majority and, to ensure territorial continuity, some ethnically mixed villages. The Gagauz would constitute $78.2 \%$ of the population of such a region. Additionally, it was proposed that other places could freely join the autonomy should they wish [Kendigelian 2009: 159-165]. 
Table 1. Ethnic composition of Moldova and its districts inhabited by the Gagauz in 1989

\begin{tabular}{|c|c|c|c|c|c|c|c|c|c|c|c|c|c|c|}
\hline \multirow{3}{*}{ Area } & \multicolumn{14}{|c|}{ Population } \\
\hline & \multicolumn{2}{|c|}{ Total } & \multicolumn{2}{|c|}{ Moldovans } & \multicolumn{2}{|c|}{ Russians } & \multicolumn{2}{|c|}{ Ukrainians } & \multicolumn{2}{|c|}{ Gagauz } & \multicolumn{2}{|c|}{ Bulgarians } & \multicolumn{2}{|c|}{ Others } \\
\hline & thou. & $\%$ & thou. & $\%$ & thou. & $\%$ & thou. & $\%$ & thou. & $\%$ & thou. & $\%$ & thou. & $\%$ \\
\hline Moldova & $4,335.4$ & 100 & $2,794.7$ & 64.5 & 562.1 & 13.0 & 600.4 & 13.8 & 153.5 & 3.5 & 88.4 & 2.0 & 136.3 & 3.2 \\
\hline $\begin{array}{l}\text { Five southern } \\
\text { districts } \\
\text { (combined) }\end{array}$ & 287.9 & 100 & 74.4 & 25.9 & 17.0 & 5.9 & 14.6 & 5.1 & 136.0 & 47.2 & 41.8 & 14.5 & 4.0 & 1.4 \\
\hline $\begin{array}{l}\text { Basarabeasca } \\
\text { district }\end{array}$ & 44.3 & 100 & 20.0 & 45.0 & 5.1 & 11.6 & 2.9 & 6.7 & 13.4 & 30.2 & 2.1 & 4.7 & 0.8 & 1.8 \\
\hline $\begin{array}{l}\text { Ceadîr-Lunga } \\
\text { district }\end{array}$ & 67.0 & 100 & 2.7 & 4.1 & 3.0 & 4.5 & 2.1 & 3.1 & 43.0 & 66.2 & 15.2 & 22.7 & 0.9 & 1.4 \\
\hline \begin{tabular}{|l|} 
Comrat \\
district \\
\end{tabular} & 70.1 & 100 & 12.8 & 18.2 & 3.3 & 4.7 & 3.3 & 4.7 & 44.7 & 63.8 & 5.2 & 7.4 & 0.8 & 1.2 \\
\hline $\begin{array}{l}\text { Taraclia } \\
\text { district }\end{array}$ & 44.8 & 100 & 7.0 & 15.7 & 3.0 & 6.7 & 3.6 & 8.1 & 12.3 & 27.5 & 18.0 & 40.2 & 0.8 & 1.8 \\
\hline $\begin{array}{l}\text { Vulcănești } \\
\text { district }\end{array}$ & 61.6 & 100 & 32.0 & 51.9 & 2.5 & 4.1 & 2.7 & 4.3 & 22.5 & 36.5 & 1.3 & 2.2 & 0.6 & 1.0 \\
\hline
\end{tabular}

Source: Nedelchuk [1992: 27].

The prevailing assertion made by researchers of the Gagauz Republic is that its territory was comprised of the five above-mentioned southern districts [Chinn, Roper 1995: 295; Crowther, Fedor 1995; King 1997: 751; Kubicek 2010: 291]. In reality, the region declared as the Gagauz Republic on August 19, 1990 comprised only those areas dominated by the Gagauz and that had expressed a desire to be part of the autonomy. Large parts of the Comrat and Ceadîr-Lunga districts were included, along with more restricted areas of the Vulcănești, Basarabeasca and Taraclia districts (Map 1). ${ }^{5}$ The borders were largely regarded as provisional, as the Gagauz leadership hoped that other localities would join the Republic; no formal claims to include all five districts were made [Kendigelian 2015; Karakash 2015]. The territory of Gagauzia declared on August 19, 1990 can be regarded as generally coinciding with its actual territory, understood to be an area of the Gagauz authorities' activities, such as holding elections and referenda. No borders were marked on the ground, just checkpoints on the main roads to the republic. It was not necessarily a unified area; indeed, Dareg A. Zabarah [2012: 187] called it "a loose conglomerate of villages".

\footnotetext{
5 These were territories of 28 local soviets (out of the total of 64 within five southern districts [Moldavskaia SSR, 1988: 11, 14-15, 40-41, 76-77, 80]): Comrat, Bugeac, Congaz, Beșalma, Chirsova, Dezghingea, Congazcic, Ferapontievca, Sadîc (only the village of Taraclia), and Cotovscoe in the Comrat district; Ceadîr-Lunga, Tomai, Gaidar, Beșghioz, Baurci, Cazaclia, and Joltai in the Ceadîr-Lunga district; Vulcănești, Etulia, Chișmichioi, and Burlăceni in the Vulcănești district; Cioc-Maidan, Avdarma, and Chiriet-Lunga in the Basarabeasca district; Copceac, Svetlîi, Cealîc, and Budăi (only the village of Carbalia) in the Taraclia district [Panorama, Aug. 23, 1990]. Another source [Sovetskaia Moldova, Aug. 22, 1990] adds parts of the sixth district of Cahul, however, they did not take part in any activities of the Gagauz Republic and were not claimed by the Gagauz authorities later on. In addition, the area of the present Autonomous Territorial Unit of Gagauzia (Gagauz Yeri) is slightly smaller than the territory of the Gagauz Republic declared on August 19, 1990, while the Gagauz share of the total population is $82.1 \%$.
} 


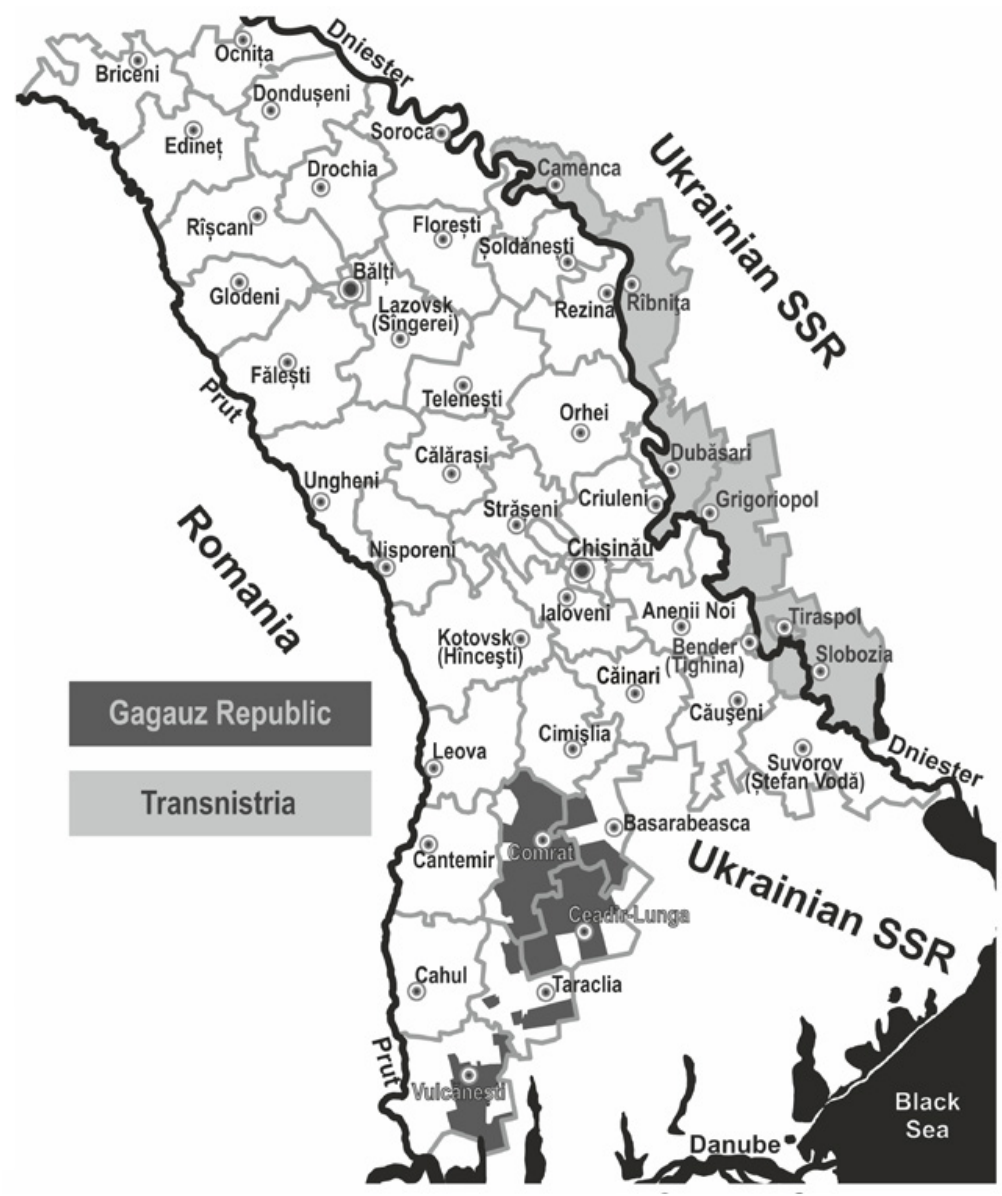

Map 1. Declared territories of the Gagauz Republic and Transnistria in 1990

Source: Drawn by Jakub Pieńkowski on the basis of information from Panorama, Aug. 23, 1990, Atlas Moldavskoi SSR [1990: 7] and Bomeshko [2010: 88].

\section{MILITARY DIMENSION}

Moldova attempted to put an end to the Gagauz Republic two months after the declaration of the separatist republic. This was directly linked with elections to the Gagauz Supreme Soviet to be held on October 28, 1990. Having no army at this time, the Moldovan government instead organised detachments of volunteers. Accompanied by police units, poorly-equipped volunteers moved on public buses to the Gagauz areas on October 25. In turn, the Gagauz had at their disposal a number of self-defence squads. They established roadblocks and dug ditches on the edges of the region and its localities, harnessing all available weapons including garden-forks, 
metal bars, Molotov cocktails, fuel tanks and small arms. Crucially, they requested and received support from the Soviet airborne division, stationed in the city of Bolgrad in Ukraine, as well as Transnistrian volunteers who came with a supply of arms. Additionally, Bulgarians from some neighbouring settlements blocked Moldovan detachments. At the same time, the Gagauz and Moldovan leaderships engaged in negotiations. All these prevented Moldovan irregulars from entering the Gagauz localities. A bloodbath was finally prevented by deployment, with the consent of both conflicting parties, of the Soviet Union's internal troops on October 28, 1990.

In August 1991, Moldova made a further attempt to put an end to the Gagauz Republic, arresting Topal and Kendigelian on a charge of supporting the Moscow Putsch. However, they were released after a month. This, and other sabotage actions by Moldova, spurred the Gagauz leadership to establish a paramilitary unit, christened the Budjak Battalion, composed of several hundred guardsmen. Interestingly, it was formally registered as a security company under Soviet/Moldovan law. The Battalion was supplied with small arms and light weaponry by Transnistria from the depots of the 14 ${ }^{\text {th }}$ Soviet/Russian Army [Burgudzhi 2015; Kendigelian 2009: 297; Topal 2013: 181-187]. Its commander, Ivan Burgudzhi [2015], claims that it also received human and material support from the Bolgrad airborne division. The Battalion's tasks were as follows: defence against invasion, counter-sabotage, control of movement of people and goods into and out the Gagauz area, and protection of Republic's authorities, institutions, and companies [Burgudzhi 2015; Kendigelian 2009: 297; Topal 2013: 181-187]. While not robust, the Budjak Battalion successfully prevented Moldovan law enforcement (and government) officials from entering freely the Gagauz region and was an important factor in deterring Moldova from regaining control over the Gagauz area by force (although one may say that such a scenario was unlikely, mainly due to Moldova's focus on growing tensions with Transnistria and, finally, losing a war with Transnistrian separatists in 1992).

Interestingly, local police in the Gagauz region, who remained loyal to the Moldovan authorities co-existed with the Budjak Battalion and the self-defence squads. On the one hand, the Gagauz leaders were distrustful of the police and feared that they could (perhaps violently) oppose the republic. Accordingly, they tried to subordinate the police, but failed mainly due to insufficient financial resources [Topal 2015; Panorama, Mar. 24, 1992]. On the other hand, the local police did not wish to meddle in politics and focused instead on keeping public order. Moreover, had Moldova launched an armed operation against the Gagauz Republic, the local police might have sided with the latter. This could potentially have happened during the so-called "march of the volunteers" on the Gagauz areas that occurred in October 1990. The local police maintained neutrality, but had the Moldovan irregulars attacked the Gagauz settlements, officers may have forsaken their allegiance to the Moldovan authorities and defended their homes and families [Dudush 2015]. Despite the fact that there were tensions between the Budjak Battalion and the local police, they normally co-existed and sometimes actively cooperated [Burgudzhi 2015; Dudush 2015]. Both were dominated by 
the Gagauz: the Battalion guardsmen and the police officers knew each other, coming as they did from small communities. Additionally, the Gagauz Republic authorities had to rely on the police with respect to keeping public order, as the Budjak Battalion was not suitable for such an activity [Dudush 2015].

The Budjak Battalion was additionally used to pressurise people reluctant to support the activities of Gagauzia's authorities [Dobrov 2015; Neikovchen 2015]. While there were serious problems with subordination of this paramilitary formation, it did not try to undermine the authority of the Gagauz leadership. It is not without significance that its commander was simultaneously the head of the Internal Affairs Department of the Gagauz government, the outcome being that the Gagauz Republic enjoyed freedom from local strongmen.

\section{POLITICAL DIMENSION}

\section{GAGAUZ REPUBLIC STATE INSTITUTIONS}

The first institution of Gagauzia, set up on the day of its proclamation on August 19, 1990, was the Provisional Committee on Establishment of the Gagauz Republic. It replaced a similar institution formed in December 1989 with the aim of establishing Gagauz autonomy within Soviet Moldova. The Provisional Committee held all powers until the Supreme Soviet was elected at the end of October 1990. While elections were originally set for October 28, they were moved to October 26 due to threats from Moldovan volunteers. Voters were not afraid and cast their ballots as early as the night of October 25. The Supreme Soviet assembled on October 30 and took power from the Provisional Committee. While the Gagauz took some steps to form a government soon after, the formal government-building process only launched in autumn 1991 [KV, Oct. 10, 1991; KV, July 6, 1992]. By early 1993 the newly formed Department of Education was able to take control of the public education departments of the Comrat, Ceadîr-Lunga, and Vulcănești districts [KV, Feb. 20, 1993; Cheshmezhdi 2015; Savastin 2015].

The president of the Gagauz Republic was elected in December 1991. Interestingly, there were discussions about whether the presidential office was needed at all. Its supporters, who finally won the debate, claimed that it would be a good opportunity to publicise the Gagauz cause and that the Republic needed a principal representative [KV, Nov. 5, 1991; Znamia, Nov. 28, 1991]. Indeed, it was the vice-president, Petr Buzadzhi, who led the Gagauz delegation to the commission that developed, together with Moldovan counterparts, a bill on the Gagauz autonomy within Moldova. The Gagauz may have also simply copied Moldova's decision to elect a president in popular elections (they were taken on December 8, 1991). With the establishment of the presidential office, power was spread between the president and the parliament (and its chairman in the first place). Additionally, with the support of the Budjak 
Battalion, the Gagauz set up their own executive committee in January 1993 in the Vulcănești district. This met with the legal Moldovan committee and took care of four Gagauz settlements located in the district [Savastin 2015; Panorama, Dec. 30, 1993]. Thus, Gagauzia established its legislative and dual executive. It did not have its own judicature, but local law enforcement agencies that were subordinated to Moldova's central authorities, just like the local police, did not interfere in politics.

Despite the establishment of the executives, the state institutions of the Gagauz Republic were not robust. This was admitted by the Gagauz elites themselves, while the greatest dissatisfaction was expressed in regard to the government; just three departments (internal affairs, education, and finance) were found to be functional [KV, Aug. 14, 1993]. The Gagauz deliberately delayed establishing state institutions in order to help stabilise relations with Moldova and to facilitate negotiations on legal recognition of the Republic by the Moldovan authorities [Kendigelian 2009: 327]. Moreover, they did not know how to properly proceed with the business of institution-building. When elected to the presidential office, Topal underlined that he was just a novice politician and that the Gagauz leadership had never dealt with state-building [Znamia, Dec. 19, 1991]. This was more than two years after proclaiming the Gagauz autonomous republic within Moldova and almost a year and half after declaring the Gagauz Republic. Indeed, Topal and Kendigelian, the top two Gagauzian leaders, were respectively a director of a road construction company and a teacher of Russian. The Gagauz leadership also had a problem with recruiting specialists. Ilia Karakash, an Odessa-based scholar of Gagauz origin, emphasised the low intellectual powers of the local Gagauz regarding political and socio-economic issues related to the concept of territorial autonomy [Panorama, May 12, 1992]. He himself authored the 1990 declaration proclaiming the Gagauz Republic and the establishment of the local university, but many Gagauz from outside the region, including from Chișinău, were reluctant to support the Republic [Karakash 2015; see also King 1997: 746-747].

Last but not least, a significant problem hindering institution-building was that the Republic's leadership had scarce financial resources at its disposal. Money came from voluntary donations made by ordinary people or worker teams, for example, for a day of their work [Znamia, Sept. 8, 1990; Znamia, June 11, 1991]. Donations were also given officially or unofficially (voluntarily or under duress) by collective farms (kolkhozes) and factories located in the Gagauz area. Substantial financial support came from Transnistria that additionally provided Gagauzia with goods such as cars, arms for the Budjak Battalion or paper for the official gazette [Kendigelian 2015; Neikovchen 2015]. Contributions were also made by the local authorities of the Comrat and Ceadîr-Lunga districts: these were either donations (accepted, at least temporarily, by Moldova) marked as "other expenses" in their budgets, or for six months during 1993 as transfers to the regional budget of the Gagauz Republic [KV, Feb. 5, 1994; KV, Nov. 5, 1994]. Funds might also have been given to the region as cash or via private bank accounts by the Soviet Union/Russia and Turkey, respec- 
tively, via Tiraspol in Transnistria and Odessa in Ukraine [Neikovchen 2015]. All in all, the financial resources were barely enough to run the state apparatus and the Budjak Battalion. There were serious problems with paying salaries, with officials not receiving them for up to a year.

\section{SHARED LOCAL ADMINISTRATIVE INSTITUTIONS}

The Gagauz Republic's leadership recognised Moldova's local administrative institutions as its own and tried to appropriate them to execute its decisions or at least to induce them to take some steps or coordinate their activities. These essentially concerned the soviets (councils) of people's deputies and their executive committees of communities from the territory of Gagauzia and of two districts of Comrat and Ceadîr-Lunga. This was of great importance for the Republic due to the weakness of its government. What benefitted the Gagauz Republic was that local elections to soviets, held in early 1990, brought many activists or supporters of the Gagauz national movement to power, and some of them simultaneously served as the Republic's officials. For example, the chairman and the deputy chairman of the Comrat District Soviet of People's Deputies - Topal and Kendigelian, respectively - held the top offices in the Gagauz Republic. In addition, opponents of the Gagauz area's separation from Moldova, especially in the early days, did not dare to go against the masses supporting the Gagauz Republic. If needed, guardsmen from the Budjak Battalion were used to enforce loyalty. Significantly, it was the deputies of the local soviets from the Gagauz area who declared the Gagauz Republic on August 19, 1990.

In reality, however, Gagauzia shared control over the local administrative institutions with Moldova. Still recognising the region's soviets and committees as its own, Moldova continued paying salaries to local officials and allocating money to local budgets. The local authorities struggled with deficits, and thus funds from the central budget was of crucial importance for the region. The only local institution fully subordinate to the Gagauz Republic's authorities - the Gagauz executive committee in the Vulcănești district - had no money for transferral to the district's communities and had to count on the legal committee's fund [Savastin 2015]. The financial dependence of the local authorities was the most powerful factor in favour of their subordination to the Moldovan centre. The financial situation was different only between May and November 1993 in the case of the Comrat and Ceadîr-Lunga districts. They contributed to the regional budget of the Gagauz Republic while their financial ties with the central budget were loosened. ${ }^{6}$

6 On relations between local budgets of the Gagauz area and central budget of Moldova as well as on the budget of the Gagauz Republic see, for example, Znamia, Dec. 17, 1991; KV, Feb. 20, 1993; KV, Nov. 13, 1993; KV, Jan. 29, 1994; KV, Nov. 5, 1994; Kendigelian [2009: 366-368]. While Sato [2009: 156] writes that the third district of Vulcănești joined the Gagauz Republic's budget too, in fact, the Gagauz leadership did not attempt to include this district because it was dominated by Moldovans [Topal 2013: 113]. 
Over time and with decreasing mobilisation of the masses, the unity of the Gagauz elites was more and more undermined. This worked against the Gagauz Republic [Angeli 2006: 158]. A long-time animosity between two centres of the Gagauz areaComrat and Ceadîr-Lunga - made itself felt too. The Ceadîr-Lunga withdrawal from the Republic's budget in November 1993 was an example of problems with unity among the Gagauz. Deputies from this district believed that their region financially subsidised the Comrat district and decided to stop doing this. The Gagauz Republic authorities blamed Bulgarians, who had a strong position in the Ceadîr-Lunga elites, and Moldova, which courted the local leadership by offering some benefits. The soviet of the Ceadîr-Lunga district also decided, against the will of the Republic's authorities, that the district would unconditionally take part in Moldova's parliamentary elections to be held in early 1994 [Kendigelian 2015; Topal 2013: 113-115].

Additionally, moderates and pragmatists made their presence increasingly felt. These were, for example, Konstantin Taushanzhi and Leonid Dobrov (the chairmen of the Comrat district and Comrat city executive committees, respectively), and Dmitrii Kroitor (the chairman of the Ceadîr-Lunga District Executive Committee). Taushanzhi and Dobrov were in favour of reaching compromises with the Moldovan authorities and, in May 1991, came up with the first plan for Gagauz territorial autonomy within Moldova, which was highly criticised by the Gagauz Republic leadership. Kroitor was a principal figure behind the Ceadîr-Lunga district's withdrawal from the budget of the Gagauz Republic in late 1993. In return, the district was supposed to get extra funds from Moldova for economic development. Finally, dual subordination of the local authorities either bred passivity of some of their representatives or gave some of them an opportunity to manoeuvre between Gagauzia's and Moldova's leaderships to their own benefit; both played against the Gagauz de facto state [KV, Nov. 7, 1991; KV, June 19, 1993]. In late 1993, Topal accused local committees of going against the Republic, and the local soviets of passivity. He tried to subordinate local administrative institutions, but soon gave up [KV, Nov. 27, 1993; KV, Feb. 12, 1994].

\section{THE EXECUTION OF POWER}

Largely due to under-development of the Gagauz Republic state institutions and a lack of full control over local administrative institutions, the majority of decisions made by the Gagauz authorities were not executed [Panorama, Jan. 31, 1991; KV, Feb. 29, 1992; Shornikov, Bulgar 2006: 417]. However, there were numerous instances where a broad consensus was reached between the leadership of the Gagauz Republic, the local authorities, and the region's population. These cases largely concerned the preservation of the old, Soviet reality while preventing the formation of a new, Moldovan order; they also involved development of the region's statehood and identity. For example, the Gagauz Republic's leadership conducted elections for both its parliament and president while simultaneously refusing to participate in the election of Moldova's president. Furthermore, in March 1991, it organised a referendum on the preservation 
of the Soviet Union (a move officially banned in Moldova) and, in December 1991, another one on establishing a separate Gagauz Republic (however, supposed to create a federation or a confederation with republics of Moldova and Transnistria) within the reorganised Soviet Union (the Union of Sovereign States). It banned the Moldovan flag from being flown over local institutions and instead flew its own flag (and that of the Soviet Union, during its existence). It also prevented people from the Gagauz area being called up to the Moldovan army, promoted the dominant position of the Russian language while downplaying the Moldovan (Romanian) language, and formed its own regional budget for six months. As summed up by Viktor Grebenshchikov, a counselor to the Moldovan president, the Gagauz region violated sovereignty and territorial integrity of Moldova [Nezavisimaia Moldova, Feb. 23, 1993].

There were also issues about which the Gagauz demonstrated pragmatism. Although they threatened to use physical force to take control over a radio station in Comrat during a politically tense period in August 1990 [Arabadzhi 2015], they later successfully cooperated with the Moldovan authorities to develop mass media, education, and economic institutions fostering the Gagauz and regional identities. This is confirmed, for example, by Ilia Afanasev [2015], the founder and director of Comrat Television, who says that whilst he could have taken two men with guns and taken control of the TV tower, he instead went to the ministry in Chișinău to register the local television station properly. Another example concerns the regional university, launched in Comrat in February 1991 due to the combined efforts of Gagauz national movement activists and public donations. When parents of students protested that the qualifications would not be universally recognised, the Gagauz applied to the Moldovan Ministry of Education for formal registration of the university and ratification of the degrees [Varban 2015]. Similarly, the head of the Gagauz government Department of Education communicated with his Moldovan counterparts to establish a Gagauz national school employing Gagauz as the language of instruction (in this case without success), or for the ability to send a group of Gagauz students to universities in Turkey [Cheshmezhdi 2015]. Gagauzia also set up a regional bank in cooperation with the Moldovan National Bank, knowing that otherwise it could not function (although initially the Gagauz negotiated just with the authorities of the Soviet Union) [Kendigelian 2015; Topal 2015]. These institutions were referred to as the greatest achievements of the Gagauz Republic when its third anniversary was celebrated [KV, Aug. 21, 1993].

\section{SOCIO-ECONOMIC DIMENSION}

While Gagauzia was dominated by the Gagauz there were fears of prejudice which was one of reasons why Bulgarians did not decide to join the Gagauz autonomy - so the Gagauz authorities pro-actively emphasised the principles of internationalism. The rights of people of all ethnic backgrounds and nationalities were guaranteed in the August 1990 proclamation of the Gagauz Republic [Deklaratsiia 2014]. As 
many as four languages (Bulgarian, Gagauz, Moldovan and Russian) were declared as official, though Russian still served as a lingua franca. All these measures were meant to maintain the Soviet ideal and contrast with Moldovan nationalism. Indeed, inter-ethnic relations were generally good.

While remaining faithful to the idea of internationalism, the Gagauz Republic's leadership nevertheless discreetly engaged in developing an identity that had been very weak until the end of the 1980s. For example, the flag, anthem, and coat of arms of the Republic were finally approved and national holidays supported. The Gagauz language was Latinised and terms such as bashkan (initially used for the mayor of Comrat and then for the governor of the autonomy) and Gagauzia or Gagauz Yeri (meaning a place where the Gagauz live) were coined at that time [Dobrov 2015; Taushanzhi 2015]. As has already been mentioned, a Gagauz university, television channel, and bank were also established. According to Alla Paptsova [2015], a (present-day) scholar from the Comrat State University, even these moderate activities were of crucial importance for the development of the Gagauz language and identity.

Undoubtedly, internationalism and moderate "Gagauzation" - main elements of nation-building - were appreciated by the inhabitants of the Gagauz area and fostered unity and identification with the Gagauz Republic. Sufficed to say that turnout in the 1991 presidential elections and associated referendum was $85.2 \%$, in which more than $95 \%$ of voters supported Topal and the "independence of the Gagauz Republic within the political and economic Union of Sovereign States" [KV, Dec. 17, 1991]. At the same time, as Paptsova [2015] underlines, people did not perceive Gagauzia as a separate entity from Moldova, or the Gagauz leadership as an alternative to the central Moldovan authorities. A crucial point is that there was no bloodbath. After the October 1990 march of Moldovan volunteers to the Gagauz Republic, there were no further open confrontations with Moldova and the parties continued talking about conflict resolution; almost all ties were retained between the Gagauz area and the rest of Moldova [see also Angeli 2006: 78-80]. The idea of autonomism was undeniably popular, as demonstrated by a referendum taken in March 1994 when almost all voters were in favour of establishing a Gagauz ethno-territorial unit within Moldova (turnout was better than $90 \%$, except in the Comrat district, where participation was only $78.3 \%$ ) [KV, Mar. 12, 1994].

To the daily benefit of the Gagauz population, the region did not experience war and maintained financial and socio-economic ties with the rest of Moldova (except in 1993 when a Gagauz budget existed for a few months). Taxes collected in the Gagauz area were sent to the Moldovan central budget, from which funds were transferred back to local budgets. Services were co-funded or funded by Moldova and provided, as previously, by central or local institutions. People continued to receive pensions from the Moldovan central budget and could freely use hospitals in Chișinău. Some of these links were more or less accepted, while other were even welcomed. Gagauzia only had money for maintaining its own institutions and could only influence expenditure of localised budgets for administrative purposes. 
However, as a result of the collapse of the Soviet Union, Moldova suffered an economic breakdown, one of the most significant among the post-Soviet republics. The standard of living drastically dropped in Moldova, including in the Gagauz area, and the problem of wage arrears was common. While the Gagauz Republic's authorities did not have the instruments to tackle the crisis, they themselves and the Republic were blamed for the problems. The leadership was accused of inactivity, money fraud and over-spending on the Republic's institutions, resulting in a price increase of basic necessities [KV, Jan. 11, 1992; KV, Oct. 29, 1994]. Additionally, due to weakened law-enforcement agencies in the collapsing Soviet Union and the emerging independent Moldova, crime rates increased substantially. Gagauzia tried, but failed, to cope with this problem. Moreover, individual guardsmen from the Budjak Battalion intimidated civilians [Panorama, Mar. 17, 1992; KV, Oct. 3, 1992], and some were themselves involved in criminal activities [Neikovchen 2015; Dudush 2015].

Topal complained that the Gagauz started their struggle for self-determination when people had had a decent life under the Soviet Union, although this soon changed and worsened the situation of the Republic [KV, Nov. 27, 1993]. Indeed, as a result of the economic crisis, people became tired with the region's undetermined status. They increasingly desired stabilisation and the striking of a deal with Moldova, the more so as Moldovan nationalists lost much of their influence after losing the war with Transnistria in mid-1992 and were finally ousted from power in the aftermath of the parliamentary elections in early 1994 [Karakash 2015; Lazarev 2015; Dobrov 2015]. The impact of the negative socio-economic situation was so deep that Topal and Kendigelian lost the first elections for the bashkan (governorship) of the Gagauz autonomy in 1995. The winner was Georgii Tabunshchik, a former first secretary of the Communist Party in the Comrat district. An opponent to the Gagauz national movement, Tabunshchik was remembered by voters as a good, Soviet administrator and represented a direct association with the prosperous Soviet past.

\section{CONCLUSIONS}

Examination of the domestic dimensions of Gagauzia's de facto statehood allows the results of state consolidation efforts undertaken by Gagauzia's leadership to be defined and reveals a nuanced picture. On the one hand, the Gagauz Republic's authorities failed to subordinate law-enforcement agencies and local administrative institutions functioning in the Gagauz area. The former remained loyal to Moldova's central authorities, while control over the latter was shared between the Gagauz and Moldovan leaders. This makes the case of Gagauzia extraordinary, given that other de facto states managed to expel representatives of parent states from most of the territory which they claim (but they may have a problem with taking control of some parts of their territory like the case of Abkhazia and the Georgian/Mingrelian-populated Gali region - Blakkisrud, Kolstø [2012: 282-284]). In addition, Gagauzia’s 
territory was not necessarily a unified area. Its own governing and military institutions were not robust and the majority of decisions made by the Gagauz authorities were not executed. Over time, unity among elites and the population's support for the Gagauz de facto state decreased.

On the other hand, however, the Gagauz leadership exerted military control over Gagauzia's territory comprising parts of Moldova's five southern districts. Decisions that were implemented, relating mainly to political and identity issues, were of great importance to Moldova because they substantially hindered the formation of its independent statehood. The Gagauz elites and population were generally unanimous in demanding their own (legalised) ethno-territorial unit, while Moldova was able to reintegrate the Gagauz area only when the Gagauz authorities agreed to a deal.

Another identified problem is that Gagauzia was dependent on Moldova in terms of finances and services. This is another outstanding feature of the Gagauz Republic. Whereas some de facto states rely on their parent states - arguably, the most prominent example is Transnistria (having an export-oriented economy) whose ability to trade legally with the outside world depends on Moldova [Blakkisrud, Kolstø 2011: 190-191] - such a dependency is limited [Caspersen 2012: 65-68]. In point of fact, Gagauzia was dependent on Moldova to such an extent that people did not perceive Gagauzia as completely separate from Moldova.

However, economic dependency and people's perception were not problematic, given that the Gagauz Republic strived for territorial autonomy within Moldova (and this is another distinctive feature, given that de facto states usually strive for independence or joining another state). Accordingly, some ties were more or less accepted, whereas others were embraced by the Gagauz authorities. Moreover, the Gagauz leadership itself sought cooperation with the Moldovan authorities to set up and develop regional non-political institutions such as a university, a television service and a bank. Their establishment was seen as one of most important achievements of the Gagauz de facto state (along with formation of governing institutions and finally getting territorial autonomy within Moldova). In its turn, Moldova was responsive to the Gagauz proposals, hoping that striking a deal with Gagauzia would help to resolve a conflict with its another breakaway region of Transnistria.

Furthermore, while other de facto states are generally not dependent on their parent states, they may rely on an external power. Being heavily dependent on subsidies from a patron (which Gagauzia did not have), the present Eurasian de facto states are a case in point [Ó Beacháin et al. 2016: 443]. For example, Russia supplies Transnistria's highly industrialised economy with natural gas free of charge as well as funds almost entire South Ossetia's budget. Striving for separation from their parent states, Eurasian de facto states accept or even welcome this dependency on a patron; as a matter of fact, they would not be able to survive without economic support and security guarantees provided by their patron [Blakkisrud, Kolstø 2012: 290-291]. In general terms, all these somehow reflect Gagauzia's economic reliance on and strategy toward Moldova. 
If compared to other de facto states, it can be said that Gagauzia scored better in state consolidation than Chechnya (1996-1999) and the Republika Srpska Krajina (RSK) (1991-1995). The former was "an example of a largely anarchic entity dominated by infighting warlords" [Caspersen 2012: 21], whereas leadership of the latter "rather than build[ing] strong state institutions (...) pilfered the state and allowed the society to slide into anarchy [and] never made any attempt to create a sense of separate RSK identity linked to the state" [Kolstø, Paukovic 2013: 309]. In addition, while the RSK was completely disbanded when absorbed into Croatia, the Gagauz region was granted autonomy within Moldova; thus, experience gained by the Gagauz elites during the existence of the de facto state of Gagauzia has been used by them in developing the newly created Autonomous Territorial Unit of Gagauzia (Gagauz Yeri) [Żyromski, Hatłas 2008].

Ultimately, therefore, it can be said that Gagauzia's leaders were moderately successful in consolidating Gagauzia's statehood through processes of state- and nation-building. As stated by Mariia Marunevich [2003: 172], one of the leaders of the Gagauz national movement, the Gagauz Republic allowed ideas of consolidation and rebirth of the Gagauz nation to be successfully tested and the first-ever Gagauz government structures to be established. It should be added, however, that state- and nation-building resources were running low during the last period of the Gagauz Republic's existence. It is likely that if Moldova had delayed matters for a year, then the Gagauz elites would have been so divided and people's mobilisation would have been so low that it would not need to grant territorial autonomy to Gagauz [Popozoglo 2015; Topal 2015].

\section{BIBLIOGRAPHY}

Afanasev, I. 2015. Founder and director of the Comrat/Gagauz television. Interview by author. Comrat, October 14.

Angeli, F. 2006. Gagauzskaia Avtonomiia: Liudi i fakty (1989-2005 gg.), Universul, Kishinev.

Arabadzhi, G. 2015. Director of the Comrat/Gagauz radio station. Interview by author. Comrat, July 9. Atlas Moldavskoi SSR. 1990. GUGK, Moskva.

Bakke, K.M., O'Loughlin, J., Toal, G. 2014. Convincing State-Builders? Disaggregating Internal Legitimacy in Abkhazia, "International Studies Quarterly", vol. 58 (3).

Batt, J. 1997. Federalism versus Nationalism in Post-Communist State-Building: The Case of Moldova, "Regional \& Federal Studies", vol. 7 (3).

Blakkisrud, H., Kolstø, P. 2011. From Secessionist Conflict Toward a Functioning State: Processes of State- and Nation-Building in Transnistria, "Post-Soviet Affairs", vol. 27 (2).

Blakkisrud, H., Kolstø, P. 2012. Dynamics of De Facto Statehood: The South Caucasian De Facto States Between Secession and Sovereignty, "Southeast European and Black Sea Studies", vol. 12 (2).

Bomeshko, B. 2010. Sozdanie, stanovlenie i zashchita pridnestrovskoi gosudarstvennosti. 1990-1992 gg., Poligrafist, Bendery.

Burgudzhi, I. 2015. Commander of the Budjak Battalion and head of the Gagauz government Internal Affairs Department. Interview by author. Comrat, July 13. 
Caspersen, N. 2012. Unrecognized States: The Struggle for Sovereignty in the Modern International System, Polity, Cambridge.

Caspersen, N., Stansfield, G. 2011. Introduction: Unrecognized states in the international system, [in:] Unrecognized States in the International System, N. Caspersen, G. Stansfield (eds.), Routledge, London.

Cheshmezhdi, A. 2015. Head of the Gagauz government Education Department. Interview by author. Phone conversation, October 29.

Chinn, J., Roper, S.D. 1995. Ethnic Mobilization and Reactive Nationalism: The Case of Moldova, "Nationalities Papers", vol. 23 (2).

Chinn, J., Roper, S.D. 1998. Territorial Autonomy in Gagauzia, "Nationalities Papers", vol. 26 (1).

Crowther, W.E., Fedor, H. 1995. Moldova, [in:] Belarus and Moldova. Country Studies, H. Fedor (ed.), Library of Congress, Washington, D.C.

Deklaratsiia o svobode i nezavisimosti gagauzskogo naroda ot respubliki Moldova, 19 avgusta 1990, Komrat. 2014, [in:] S"ezdy gagauzskogo naroda: Deputaty vsekh urovnei, deputaty vsekh sozyvov narodnogo sobraniia Gagauzii, N. Dimitroglo, Komrat.

Dobrov, L. 2015. Principal member of the Gagauz national movement and chairman of the Comrat City Executive Committee. Interview by author. Comrat, July 11.

Dudush, P. 2015. Comrat-based senior police investigator. Interview by author. Comrat, October 14.

Florea, A. 2014. De Facto States in International Politics (1945-2011): A New Data Set, "International Interactions", vol. 40 (5).

Graney, K. 2004. Chechnya, [in:] De Facto States: The Quest for Sovereignty, T. Bahcheli, B. Bartmann, H. Srebrnik (eds.), Routledge, London.

Karakash, I. 2015. Principal lawyer of the Gagauz national movement. Interview by author. Odessa, August 29.

Kaufman, S.J. 2001. Modern Hatreds: The Symbolic Politics of Ethnic War, Cornell University Press, New York.

Kendigelian, M. 2015. Chairman of the Gagauz Republic's parliament. Interview by author. Comrat, October 15.

Kendigelian, M. 2009. Gagauzskaia Respublika: Bor'ba gagauzov za natsional'noe samoopredelenie. 1989-1995. Vospominaniia. Dokumenty, Komrat.

King, C. 1997. Minorities Policy in the Post-Soviet Republics: The Case of the Gagauzi, "Ethnic and Racial Studies", vol. 20 (4).

King, C. 2000. The Moldovans: Romania, Russia, and the Politics of Culture, Hoover Institution Press, Stanford, CA.

Kolstø, P., Blakkisrud, H. 2008. Living with Non-recognition: State- and Nation-building in South Caucasian Quasi-States, "Europe-Asia Studies", vol. 60 (3).

Kolstø, P., Paukovic, D. 2013. The Short and Brutish Life of Republika Srpska Krajina: Failure of a De Facto State, "Ethnopolitics", vol. 13 (4).

Kubicek, P. 2010. Structure, Agency, and Secessionism in the Soviet Union and Post-Soviet States, [in:] Secession as an International Phenomenon: From America's Civil War to Contemporary Separatist Movements, D.H. Doyle (ed.), University of Georgia Press, Athens.

Lazarev, V. 2015. Present-day historian from Ceadîr-Lunga. Interview by author. Skype conversation, November 1.

Markedonov, S. 2015. De Facto Statehood in Eurasia: A Political and Security Phenomenon, "Caucasus Survey", vol. 3 (3).

Marunevich, M. 2003. Kurs lektsii dlia vuza: Istoriia gagauzskogo naroda (uchebnoe posobie), Komrat.

Moldavskaia SSR. Administrativno-territorial'noe ustroistvo. 1988. Kartia Moldoveniaske, Kishineu.

Nedelchuk, V. 1992. Respublika Moldova, Universitas, Kishinev.

Neikovchen, V. 2015. Press secretary of parliamentary chairman and president of the Gagauz Republic. Interview by author. Comrat, October 15 .

Neukirch, C. 2002. Autonomy and Conflict Transformation: The Case of the Gagauz Territorial Autonomy in the Republic of Moldova, [in:] Minority Governance in Europe, K. Gál (ed.), Open Society Institute, Budapest. 
Ó Beacháin, D., Comai, G., Tsurtsumia-Zurabashvili, A. 2016. The Secret Lives of Unrecognised States: Internal Dynamics, External Relations, and Counter-Recognition Strategies, "Small Wars \& Insurgencies", vol. 27 (3).

Paptsova, A. 2015. Present-day scholar at the Comrat State University. Interview by author. Comrat, July 10. Popozoglo, D. 2015. Comrat-based journalist. Interview by author. Comrat, July 13.

Roper, S.D. 2001. Regionalism in Moldova: The Case of Transnistria and Gagauzia, "Regional \& Federal Studies", vol. 11 (3).

Sato, K. 2009. Mobilization of Non-Titular Ethnicities During the Last Years of the Soviet Union: Gagauzia, Transnistria, and the Lithuanian Poles, "Acta Slavica Iaponica", vol. 26.

Savastin, I. 2015. Member of the Gagauz executive committee in the Vulcănești district. Interview by author. Skype conversation, October 30.

Shornikov, P. 2006. Dvizhenie gagauzskogo naroda za avtonomiiu v period krizisa SSSR, [in:] Istoriia $i$ kul'tura gagauzov: Ocherki, S. Bulgar (ed.), Pontos, Komrat-Kishineu.

Shornikov, P., Bulgar, S. 2006. Gagauzskaia Respublika. Ot konflikta k vzaimoponimaniiu i natsional'nomu soglasiiu 1991-1994 gg., [in:] Istoriia i kul'tura gagauzov: Ocherki, S. Bulgar (ed.), Pontos, Komrat-Kishineu.

Taushanzhi, K. 2015. Chairman of the Comrat District Executive Committee. Interview by author. Comrat, October 14

Thompson, P. 1998. The Gagauz in Moldova and Their Road to Autonomy, [in:] Managing Diversity in Plural Societies: Minorities, Migration and Nation-Building in Post-Communist Europe, M. Opalski (ed.), Forum Eastern Europe, Ottawa.

Tishkov, V. 2004. Chechnya: Life in a War-Torn Society, University of California Press, Berkeley.

Topal, S. 2015. President of the Gagauz Republic. Interview by author. Comrat, July 9.

Topal, S. 2013. Po zovu predkov, Komrat.

Varban, S. 2015. Founder and dean of the Agro-technological Faculty at the Comrat State University. Interview by author. Comrat, July 9 .

Webster, J.A. 2007. Parliamentary Majorities and National Minorities. Moldova's Accommodation of the Gagauz, Ph.D. thesis (University of Oxford).

Zabarah, D.A. 2011. Nation- and Statehood in Moldova: Ideological and Political Dynamics Since the 1980s, Harrassowitz, Wiesbaden.

Zabarah, D.A. 2012. Opportunity Structures and Group Building Processes: An Institutional Analysis of the Secession Processes in Pridnestrovie and Gagauzia between 1989 and 1991, "Communist and Post-Communist Studies", vol. 45 (1-2).

Żyromski, M., Hatłas, J. 2008. Power, Administration and Ethnic Minorities: The Case Study of Gagauzian Autonomy, Adam Mickiewicz University, Poznań.

\section{BIOGRAPHY}

Marcin Kosienkowski, $\mathrm{PhD}$, is an assistant professor at the Institute of Political Science and International Affairs of the John Paul II Catholic University of Lublin, Poland. His research focuses on de facto states and Moldova, including its breakaway region of Transnistria and autonomous region of Gagauzia. Kosienkowski is co-editor (with William Schreiber) and author of Moldova: Arena of International Influences (Lexington Books, 2012) and the author of The Pridnestrovian Moldavian Republic: Survival Determinants [Polish] (Wydawnictwo Adam Marszałek, 2010). E-mail: kosienkowski@kul.pl 